\title{
Music Education in Krasnoyarsk as a Resource Factor for Building the Civic Solidarity: The Situation by the Outbreak of the War
}

Yulia A. Kolpakova ${ }^{a}$, Nina P. Shutova ${ }^{b}$

FSBEI of HE "Dmitri Hvorostovsky Siberian State Academy of Arts",

Krasnoyarsk, Russian Federation.

a (iD ORCID: https://orcid.org/0000-0003-3630-8499, e-mail: gellarousse@mail.ru

b (iD ORCID: https://orcid.org/0000-0002-5770-7934

Abstract: The purpose of the study is a comprehensive analytical review of various sources that reveal the role of music in Krasnoyarsk by the outbreak of the war.

A hypothesis: interdependence of cultural and social events and their mutual influence during a period of increased social tension could be observed.

Methods. During the study the following research methods were applied: cultural-historical, axiological, continuous sampling, descriptive methods and elements of statistical research. Materials published on the pages of the Krasnoyarsk periodicals for 1937-1941, as well as scientific works about music education and music culture by various outstanding scientists were used.

Results. It was proved that music education by the outbreak of the war is considered a foundation for the realization of ideological and educational purposes. And it is also outlined that The Great Patriotic War set new challenges in the cultural life of the Krasnoyarsk Territory in general and Krasnoyarsk in particular.

It is concluded that music education is considered a resource for the national solidarity building. Due to such a strong foundation, music education at the beginning of the war was able to fulfil an ideological function while concert musical activities were used as a tool for creating of civic identity.

Keywords: civic identity, cultural life in Krasnoyarsk at the beginning of the war, music education in Krasnoyarsk.

Acknowledgments: The study was supported by the Regional State Autonomous Institution "Krasnoyarsk Regional Fund for Support of Scientific and Scientific-Technical Activities". The full name of the project is "The Art Culture in the Krasnoyarsk Territory in 1941-1945 as a Means of Forming the Civic Identity".

For citation: Kolpakova Y.A., \& Shutova N.P. (2020). Music Education in Krasnoyarsk as a Resource Factor for Building the Civic Solidarity: The Situation by the Outbreak of the War. Razvitie obrazovaniya = Development of education, 3(9), 49-53. DOI:10.31483/r-86221.

\section{Музыкальное образование Красноярска как ресурсообеспечивающий фактор формирования гражданской общности: ситуация к началу войны}

\author{
Колпакова Ю.А. ${ }^{\text {, Шутова Н.П. }}{ }^{\mathrm{b}}$ \\ ФГБОУ ВО «Сибирский государственный институт искусств имени Дмитрия Хворостовского», \\ Красноярск, Российская Федерация. \\ ID ORCID: https://orcid.org/0000-0003-3630-8499, e-mail: gellarousse@mail.ru \\ b iD ORCID: https://orcid.org/0000-0002-5770-7934
}

\begin{abstract}
Резюме: Цель исследования - комплексный аналитический обзор различных источников, раскрывающих роль музыки в Красноярске в начале войны.

Гипотеза: наблюдалась взаимозависимость культурных и социальных событий и их взаимовлияние в период повышенной социальной напряженности.

Методы исследования. В ходе исследования были использованы следующие методы: культурно-исторический, аксиологический, описательный, метод сплошной выборки и элементы метода статистического исследования. Были использованы материалы, опубликованные на страницах Красноярских периодических изданий в 1937-1941 годы, а также научные труды о музыкальном образовании и музыкальной культуре различных выдающихся ученых.

Результаты. Было доказано, что музыкальное образование к началу войны стало основой для реализации идейно-воспитательных целей. Также отмечается, что Великая Отечественная война поставила новые задачи в культурной жизни Красноярского края в целом и Красноярска в частности.

Делается вывод о том, что музыкальное образование в Красноярске рассматривается как ресурс для формирования национальной общности у народа. Благодаря такому прочному фундаменту, музыкальное искусство в начале войны выполняло идеологическую функцию, а концертная музыкальная деятельность служила инструментом для создания гражданской идентичности.
\end{abstract}

Ключевые слова: гражданская общность, культурная жизнь Красноярска в начале войны, музыкальное образование Красноярска.

Благодарности: Исследование выполнено при поддержке краевого государственного автономного учреждения «Красноярский краевой фонд поддержки научной и научно-технической деятельности». Полное название проекта: Художественная культура Красноярского края 1941-1945 гг. как средство конструирования гражданской идентичности.

Для цитирования: Колпакова Ю.А. Музыкальное образование Красноярска как ресурсообеспечивающий фактор формирования гражданской общности: ситуация к началу войны / Ю.А. Колпакова, Н.П. Шутова // Развитие образования. - 2020. - № 3 (9). - C. 49-53. DOI:10.31483/r-86221. 


\title{
Красноярскра нике̌сленӗ музыка ве̌рене̌ве̌ - гражданлӑх пе̌рлӗхне тума хӑват паракан витӗмлӗ вӑй: вӑрс̧ӑ умӗнхи лару-тӑру
}

\section{Колпакова Ю.А. ${ }^{\text {a }}$, Шутова Н.П.}

AB «Дмитрий Хворостовский яче̌лле̌ С̧е̌пе̌р патшалӑх искусство институче̌» ФПБВУ, Красноярск, Рас̧с̧ей Федерацийӗ.

a iD ORCID: https://orcid.org/0000-0003-3630-8499, e-mail: gellarousse@mail.ru

b (iD ORCID: https://orcid.org/0000-0002-5770-7934

\begin{abstract}
Аннотаци: Те̌пчев те̌ллеве̌ - вӑрс̧ӑ пус̧ламӑше̌нче Красноярскра музыка пе̌лтере̌ше̌ ме̌нле пулнине каласа паракан расна с̧ӑл кус̧а нумай енлӗ тишкерӱ тӑвасси.

Гипотеза: культурӑпа халӑх пурнӑс̧е̌нче пулса иртекен пулӑмсем пе̌р-пе̌ринпе тачӑ с̧ыхӑнни тата пе̌р-пе̌рне вите̌м кӱни курӑнмалла.

Тӗпчев меслече̌сем. Те̌пчев ирттерне̌ май с̧акнашкал меслетсемпе усӑ курнӑ: культурӑпа истори меслече̌, аксиологи, сӑнлав, пе̌те̌ме̌шле суйласа илӱ меслече̌, статистика меслече̌н элеменче̌сем. Красноярскӑн хас̧ат-журнале̌н страницисенче 1937 - 1941 с̧улсенче пичетленне̌ материалпа тата паллӑ ученӑйсем музыка ве̌ренӗве̌пе музыка культури с̧инчен с̧ырнӑ ӑслӑлӑх литературипе усӑ курнӑ.

Результатсем. Музыка ве̌рене̌ве̌ вӑрс̧ӑ уме̌нхи суулсенче идея енчен ӑс памалли нике̌с пулнине е̌нентерне̌. Тӑван с̧е̌р-шывӑн Аслӑ вӑрс̧и пе̌те̌м Красноярск крайе̌н, пайӑррӑн Красноярск хулин культура пурнӑс̧е̌ умне с̧е̌нӗ задачӑсем лартнине палӑртнӑ.

Пе̌те̌млетӱре каланӑ тӑрӑх, Красноярскӑн музыка ве̌рене̌ве̌ халӑхӑн наци пе̌рле̌хне аталанса с̧ире̌плетмелли вӑй пулнине кӑтартнӑ. С̧ак хӑватлӑ нике̌се пуррине кура музыка искусстви вӑрс̧ӑ пус̧ламӑше̌нче идеологи е̌с̧не тунӑ, музыка концерт е̌с̧е̌-хе̌ле̌ гражданлӑх пе̌рле̌хне тумалли хате̌р пулса тӑнӑ.
\end{abstract}

Tӗп сӑмахсем: гражданлӑх пе̌рле̌хе̌, Красноярск культурин вӑрс̧ӑ уме̌нхи пурнӑс̧е̌, Красноярскӑн музыка ве̌рене̌ве̌.

Тав тӑву: Те̌пчеве крайӑн «Красноярск крайе̌н ӑслӑлӑха тата ӑслӑлахпа техника е̌с̧-хе̌лне хунтӑ памалли фонче̌» патшалӑх автономи учрежденийе̌ пулӑшнипе ирттерне̌. Проектӑн тулли яче̌ - «Красноярск крайе̌н 1941 - 1945 с̧улсенче аталаннӑ илемле̌х культури гражданлӑх пе̌рле̌хне хайламалли хате̌р пулни».

Цитатӑлама: Колпакова Ю.А. Красноярскра нике̌слене̌ музыка ве̌рене̌ве̌ - гражданлӑх пе̌рлӗхне тума хӑват паракан вите̌мле̌ вӑй: вӑрс̧ӑ уме̌нхи лару-тӑру / Ю.А. Колпакова, Н.П. Шутова // Вӗренў аталанӑвӗ. - 2020. № 3 (9). - C. 49-53. DOI:10.31483/r-86221.

\section{Introduction}

The study was carried out to understand the role of art in the regions during the war, in particular in the Krasnoyarsk Territory. This article is devoted to Krasnoyarsk. Previously, the art of the Krasnoyarsk Territory was studied within the framework of art history, through the cataloging of material, analysis of artworks whereas this study starts a series of articles devoted to the problems of the civic identity building in the Krasnoyarsk Territory in 1941-1945 through musical and concert activities. It gives characteristics to the situation with music education as a resource for the cultural environment formation in the city of Krasnoyarsk, which could make it possible to use art as a tool for creating a national community. The purpose of this study is a comprehensive analytical review of various sources that reveal the role of music in the Krasnoyarsk Territory during the war. A hypothesis is put forward about the interdependence of cultural and social events and their mutual influence during a period of increased social tension.

\section{Research Methods}

The article is based on materials published on the pages of the Krasnoyarsk periodicals for 1937-1941, as well as scientific works about music education and music culture by L.V. Gavrilova, M.M. Chikhacheva, I.V. Belonosova, E.V. Prygun, E.S. Tsareva, E.A. Vanyukova and L.G. Lavrusheva. The research uses the following methods: cultural-historical method, axiological method, continuous sampling method, elements of the descriptive method and the method of statistical research.

\section{Results}

It should be noted that the subject of music education in Krasnoyarsk has been deeply studied by several scientists. For instance, the monograph "To Teach Creativity! Concerning the history of professional education in the field of art in Krasnoyarsk" is worth mentioning [6]. According to this work, before the outbreak of the Great Patriotic War, the musical cultural life in Krasnoyarsk was quite active. E.V. Prygun gives an overall picture of the cultural musical life development of the city and distinguishes four periods of its formation [5]. By 1941, the National Conservatoire had been functioning for about 20 years. Pianists, singers, string and brass players and future voice teachers graduated from the first professional music institution on a regular basis. Before the conservatoire was established, pupils at Krasnoyarsk primary and secondary educational institutions had had the opportunity to study music at singing and music classes. They learned to play musical instruments, sang in the choir, and played in the orchestra. The students also took part in concerts. Fortunately, in Krasnoyarsk by that time there were venues necessary for the functioning of creative teams. It was this fact that largely determined the further development of cultural events in Krasnoyarsk, and the city turned into a Siberian musical centre. The purpose of the conservatoire was to teach all those wishing the basics of general music education for three age categories. A couple of years later, the conservatoire was renamed into a music technical school, and in 1936 into a music college. The first separate music school was opened in Krasnoyarsk in 1930. Before 1930 , the primary and the secondary levels of professional music education were united at the conservatoire. 
Besides the National Conservatoire, by the outbreak of the war there were the Philharmonic Society (whose slogan on the posters was "Music to the masses"), the Regional Concert and Variety Bureau, the Pushkin Theatre with drama, opera, and operetta companies, orchestras (symphonic, Great Russian and mandolin-symphonic orchestras), the County Exemplary Choir headed by S.F. Abayantsev. Due to the Slovtsovs, an opera group was created, and opera performances were a great success with the public. Lack of funding at the National Conservatoire led to teachers' various part-time jobs in different musical groups and orchestras. Also, teachers had to give private lessons. Apart from professional activities, there were hobby clubs for choir and musical instrument practice. The situation of that time is described in detail in the second volume of "Musical culture of Krasnoyarsk" [4].

Refugees, prisoners of the First World War (some of them had academic music education) as well as White Guards contributed to Krasnoyarsk music culture too. For instance, local authorities organized a three-month training course for music specialists to transfer knowledge from Europeans to Siberians. E.S. Tsareva gives much interesting information on the prisoners-of-war symphony orchestra that entertained Krasnoyarsk citizens with both classical masterpieces and popular dance and folk music [6].

The composer, teacher, founder of Krasnoyarsk professional music education P.I. Ivanov-Radkevitch created the first mixed choir consisting of Krasnoyarsk students and organized a symphony orchestra of city music lovers and students. He also staged opera scenes and a children's opera with the participation of the pupils.

There was also some theoretical background. For example, K.N. Sementovsky lectured in musical arts at the University of Culture for the Krasnoyarsk party, Komsomol and Union Activists. He also made opening remarks before concerts and performances, wrote reviews and articles for the periodical "Krasnoyarsky Rabotchy", broadcast on the radio, combining these activities with pedagogic work at schools and colleges. Moreover, a musical lecture institution for senior pupils and students was created. In the Regional House of Folk Art, refresher training for leaders of amateur art hobby clubs took place. As for non-professional activities, plant employees lived an amateur musical life. There was also a choir and a brass band at the pedagogical university.

Despite the fact that the Great Russian Orchestra at the Red October club, the best Krasnoyarsk amateur group in 1925 (piccolo, domra prima I, domra prima II, domra alto I, domra alto II, domra bass I, domra bass II, balalaika prima, balalaika second, balalaika alto, balalaika bass), ceased to exist four years before the outbreak of the war, musicians playing the folk instruments continued to participate in Krasnoyarsk musical life. Before the disbandment, the repertoire of the orchestra included transcriptions of works by Russian and foreign classics (Georges Bizet, Camille Saint-Saëns, Vittorio Monti, Frédéric Chopin, etc.) as well as fantasies based on Russian folk songs ("Barynia /a mistress/1", "Vo piru byla /I was having a feast/", etc.). In addition to the fact that the head of the orchestra G.I. Troshin conducted and sometimes performed himself, he often carried out the instrumentation of the pieces. The orchestra sometimes played the music written by its conductor too.

In the 1930s, the tour poster was diverse: Leningrad Ballet, Novosibirsk and Irkutsk opera companies, vocal quartets (the Moscow Art Theatre School-Studio Quartet and Lysenko Quartet), the Travelling Opera Ensemble, the Auer Quartet, the Glazunov Quartet, the David Oistrakh and Yuri Bryushkov's Duet, the Nathan Perelman (piano) и Hertz Tsomyk's (cello) Ensemble, soloists Miron Poliakin (violin), Grigory Ginzburg (piano), Vera Dulova (harp) and many others. In 1940, the citizens has opportunity to attend the performances of the State Song and Dance Ensemble of the North Ossetian Autonomous Soviet Socialist Republic and the Leningrad State Academic Capella under the direction of A.V. Sveshnikov, the jazz orchestra of the composer Dmitry Pokrass (the program included new songs "May Moscow", "If tomorrow will be war", "Rifle", "Farewell Komsomol Song", etc.).

Thus, on the eve of the war, both art education and amateur performing were largely developing. Also cultural life was very active: musicians were working, educational institutions were teaching students and organizing concerts and musical and literary evenings as well. Even on the last pre-war day of preparing the layout, the newspaper "Krasnoyarsk Rabochy" reported about the concert of the Lviv State Theatrical Jazz under the direction of I. Gert and about One Farewell Tour of the A.M. Gorky Central Park of Culture and Leisure (Green Theatre) [1, p. 4].

At the beginning of the war, Krasnoyarsk turned into one of the defense centres with factories operating at that time to help the front. Both the preparation of reserves for the front and the formation of military units took place. Nevertheless, musical life in the city continued to intensify: in addition to concerts given by the symphony orchestra, opera theatre, chamber music soloists and groups, there were also performances in hospitals, military units, industrial enterprises and collective farms. Many musicians and professors from the state universities as well as Dnepropetrovsk and Odessa opera and ballet theatre artists were evacuated to Krasnoyarsk. This fact also played a great role. Evidently, there was not only patriotic theme, anthems and military songs. On the one hand, people were preparing to defend the country; on the other hand, people were trying to create an illusion of peace and to believe that life went on. Musical comedies staged at the Pushkin Theatre prove it. It is not surprising, as they are laughter, light music, an interesting plot, the illusion that everything is fine, that life goes on as usual. This is an opportunity to go to the theatre, to get away, to smile, to listen to well-known motives familiar to people even before the war. As for the folk songs performed at the concerts, they are also people's culture, because everyone can sing along to them. It is also a kind of identity, civic solidarity consciousness and national folklore awareness. Folklore can represent slow long melodies, love and dance songs. This is a part of the culture; it also forms the patriotic spirit. Therefore, victorious patriotic creativity arose precisely at the moment. At the same time, the war did not cancel the achievements of previous years, but brought something new to the concert activity. 
Undoubtedly, events taking place on the international political scene and news from the front presented by the media influenced the cultural development of the city and mobilized all the forces. Not only scientists, engineers, technicians, but also writers, poets and artists were inspired to hard work and dedication. The newspaper "Krasnoyarsk Rabotchy" also encouraged people to this: «Может ли быть что-либо выше, жизненнее, священнее для советского патриота, как отдать все силы на защиту советского отечества, если надо, то и саму жизнь, чтобы он мог сказать вместе с Владимиром Маяковским: «Я с теми, Кто вышел Строить И месть В сплошной лихорадке Буден. Отечество Славлю, Которое есть, Но трижды - Которое будет2» [2, p. 2].

Thus, the hypothesis is confirmed. Music education by the outbreak of the war can be considered as a foundation for the realization of ideological and educational purposes. The Great Patriotic War set new challenges in the cultural life of the Krasnoyarsk Territory in general and Krasnoyarsk in particular.

\section{Discussion}

The study strengthens the considerable work on music education and musical culture in Krasnoyarsk done by the scientists and deepens it going into the civic identity aspect. Due to such a resource as long-term music education (both in the direct academic sense, and in terms of transferring knowledge from experienced masters to amateur students), musical art was able to fulfil an ideological function for the formation of the civic solidarity among the population. They managed to create a fairly dense cultural environment where there were plenty of opportunities to use musical activities as a tool for bringing people together. The way of using these opportunities will be described in the following works. The research will be continued within the framework of the war period in the Krasnoyarsk Territory.

\section{Nota bene}

1) Hereinafter the translation is made by the authors.

2) Can there be anything higher, more vital, and more sacred for a Soviet patriot, than to devote all the efforts to defend the Soviet homeland, and if necessary, then life itself, so that one could say together with Vladimir Mayakovsky: "I am with those who went out to build and sweep in a continuous fever of the weekdays. I am glorifying the Homeland, which exists, but I am glorifying three times - the Homeland that will be".

\section{References}

1. (1941). "Krasnoiarskii rabochii", No. 145. Krasnoyarsk: State Universal Scientific Library of Krasnoyarsk Region. Retrieved from https://irbis128.kraslib.ru/?id=FT/ShowFT\&sid=4fc6d8ab5ca8152b2d522c046ed56ba5\&viewerType=G UNBKK\&squery $=\mathrm{v} 101949 / 15$

2. (1941). "Krasnoiarskii rabochii", No. 148. Krasnoyarsk: State Universal Scientific Library of Krasnoyarsk Region. Retrieved from https://irbis128.kraslib.ru/?id=FT/ShowFT\&sid=8f350e74a4ea45a070a5dbf2fb546070\&viewerType=G UNBKK\&squery $=\mathrm{v} 101949 / 15$

3. (2009). Muzykal'naia kul'tura Krasnoiarska: Vol. 1: 1628-1920., 454. Elovskaya, N. A., \& Gavrilova, L. V. (eds.). Krasnoyarsk. Retrieved from http://akademia.4net.ru/action.php?kt_path_info=ktcore.SecViewPlugin.actions. document\&fDocumentId=1132

4. (2011). Muzykal'naia kul'tura Krasnoiarska: Vol. 2: 1920-1978., 612. Kholodova, M. V., \& Gavrilova, L. V. (eds.). Krasnoyarsk. Retrieved from http://akademia.4net.ru/action.php?kt_path_info=ktcore.SecViewPlugin.actions. document\&fDocumentId=1133

5. Prygun, E. V. (2007). Iz istorii muzykal'noi kul'tury Krasnoiarska: ot "besovskikh igr" skomorokhov k Narodnoj konservatorii (1628-1920)., 237. Krasnoyarsk: KaSS. Retrieved from http://akademia.4net.ru/action.php?kt_path_ info=ktcore.SecViewPlugin.actions.document\&fDocumentId=1183

6. Baulina, V. G., et al. (2019). Uchit' tvorchestvu! K istorii professional'nogo obrazovaniia v oblasti iskusstva v Krasnoiarske., Moskaliuk, M. V., \& Chikhacheva, M. M. (eds.)., 388.

7. Tsareva, E. S., Beniumov, M. I. (1978). Voennoplennye pervoi mirovoi voiny v muzykal'noi zhizni Krasnoiarska. Iskusstvo glazami molodykh., Vinokurova, N. V., Voitkevich, S. G., Elovskaia, N. A. et al. (eds.)., 205211. Krasnoyarsk. Retrieved from http://akademia.4net.ru/action.php?kt_path_info=ktcore.SecViewPlugin.actions. document\&fDocumentId=932

\section{Список литературы}

1. «Красноярский рабочий»: краевая общественно-политическая газета. - Красноярск: ГУНБ. - №145 от 22 июня 1941 [Электронный ресурс]. - Режим доступа: https://irbis128.kraslib.ru/?id=FT/ShowFT\&sid=4fc6d8ab5ca8152 b2d522c046ed56ba5\&viewerType=GUNBKK\&squery=v101949/15

2. «Красноярский рабочий»: краевая общественно-политическая газета. - Красноярск: ГУНБ. - №148 от 25 июня 1941 [Электронный ресурс]. - Режим доступа: https://irbis128.kraslib.ru/?id=FT/ShowFT\&sid=8f350e74a4ea45a 070a5dbf2fb546070\&viewerType=GUNBKK\&squery $=\mathrm{v} 101949 / 15$

3. Музыкальная культура Красноярска: Т. 1: 1628-1920 / Красноярская государственная академия музыки и театра (с 1978-2000 и с 26.11.2015 по 09.11.2018 - КГИИ); отв. ред. Л.В. Гаврилова; ред. Н.А. Еловская. - Красноярск: [б.и.], 2009. - 454 с. [Электронный ресурс]. - Режим доступа: http://akademia.4net.ru/action.php?kt_path_info=ktcore. SecViewPlugin.actions.document\&fDocumentId=1132 
4. Музыкальная культура Красноярска: Т. 2: 1920-1978 / Красноярская государственная академия музыки и театра (с 1978-2000 и с 26.11.2015 по 09.11.2018 - КГИИ); отв. ред. Л.В. Гаврилова; ред. М.В. Холодова. - Красноярск: [б.и.], 2011. - 612 с. [Электронный ресурс]. - Режим доступа: http://akademia.4net.ru/action.php?kt_path_info=ktcore. SecViewPlugin.actions.document\&fDocumentId=1133

5. Прыгун Е.В. Из истории музыкальной культуры Красноярска: от «бесовских игр» скоморохов - к Народной консерватории (1628-1920) / Е.В. Прыгун. - Красноярск: КаСС, 2007. - 237 с. [Электронный ресурс]. - Режим доступа: http://akademia.4net.ru/action.php?kt_path_info=ktcore.SecViewPlugin.actions.document\&fDocumentId=1183

6. Учить творчеству! К истории профессионального образования в области искусства в Красноярске [Текст]/ В.Г. Баулина [и др.]; под общ. ред. М.В. Москалюк; ред. М.М. Чихачева; Сибирский государственный институт искусств имени Дмитрия Хворостовского, 2019. - 388 с.

7. Царева Е.С. Военнопленные первой мировой войны в музыкальной жизни Красноярска / Е.С. Царева, М.И. Бенюмов // Искусство глазами молодых: материалы II Международной (VI Всероссийской) научной конференции студентов, аспирантов и молодых ученых 8 апреля 2010 г. / Красноярская государственная академия музыки и театра (с 1978-2000 и с 26.11.2015 по 09.11.2018 - КГИИ); редкол. Н.В. Винокурова, С.Г. Войткевич, Н.А. Еловская, [и др.]. - Красноярск: [б.и.], 2010. - С. 205-211 [Электронный ресурс]. - Режим доступа: http://akademia.4net. ru/action.php?kt_path_info=ktcore.SecViewPlugin.actions.document\&fDocumentId=932

Информация об авторах Колпакова Юлия Андреевна старший преподаватель, переводчик ФГБОУ ВО «Сибирский государственный институт искусств имени Дмитрия Хворостовского», Красноярск, Российская Федерация. Шутова Нина Петровна доцент, заведующая секцией ФГБОУ ВО «Сибирский государственный институт искусств имени Дмитрия Хворостовского», Красноярск, Российская Федерация.
Information about the authors

Yulia A. Kolpakova - senior lecturer, interpreter of FSBEI of HE

"Dmitri Hvorostovsky Siberian State Academy of Arts", Krasnoyarsk, Russian Federation.

Nina P. Shutova - associate professor, head of section of FSBEI of HE "Dmitri Hvorostovsky Siberian State Academy of Arts", Krasnoyarsk, Russian Federation.

\section{Авторсем с̧инчен пёлтерни} Колпакова Юлия Андреевна $\mathrm{AB}$ «Дмитрий Хворостовский яче̌лле̌ С̧е̌пе̌р патшалӑх искусство институче̌» ФПБВУ аслӑ пеподавателе̌, тӑлмаче̌, Красноярск, Рас̧сеей Федерацийӗ.

\section{Шутова Нина Петровна -} доцент, АВ «Дмитрий Хворостовский яче̌лле̌ С̧е̌пе̌р патшалӑх искусство институче̌» ФПБВУ секци ертӱс̧и, Красноярск, Рас̧с̧ей Федерацийӗ. 